\title{
Textual Criticism, Translation Studies, and Symmachus's Version in the Book of Job
}

\author{
Alison Salvesen \\ Centre for Hebrew and Jewish Studies, University of Oxford, Oxford, U K \\ alison.salvesen@orinst.ox.ac.uk
}

\begin{abstract}
The late second century $\mathrm{CE}$ translator/reviser Symmachus took a very different approach to the versions of his predecessor Aquila. His renderings do not appear to have survived in Jewish circles but were much admired by early Christian scholars, thanks to their preservation in Origen's Hexapla. However, for textual critics of the Hebrew Bible Symmachus' free approach has limited his value since his readings cannot be easily retroverted, unlike those of Aquila or Theodotion. In the case of the book of Job, although Symmachus' "transformations" (to use a term from Descriptive Translation Studies) differ in nature from the freedoms observed in oG Job, while rejecting the narrow isomorphism of Aquila and Theodotion he nevertheless adheres quite closely to his Hebrew Vorlage. This offers the possibility of identifying elements significant for textual criticism in his rendering, including variant reading traditions or a different consonantal text.
\end{abstract}

\section{Keywords}

Book of Job - Descriptive Translation Studies - Symmachus - Aquila - Theodotion textual criticism - isomorphism

\section{$1 \quad$ Introduction}

Since Textus focuses on textual criticism, it may seem questionable to offer a contribution on the fragmentary renderings of a famously free translator in a notoriously difficult Hebrew book. Can Symmachus (Sym.) offer anything to the text-critical study of Job? In the past I have argued that modern com- 
mentators should take the 'Three' Jewish Greek revisers more seriously in this respect. ${ }^{1}$ However, in contrast to his predecessors Aquila and Theodotion, Sym.'s approach to rendering his Hebrew Vorlage is far less predictable. Such inconsistency produces attractive renderings that were much admired in antiquity, but creates problems for using his version in textual criticism because it is difficult to retrovert his readings.

\section{The Use of Ancient Versions in Textual Criticism}

Despite the Dead Sea discoveries in the mid-twentieth century, the role of the versions (LXX, Targum, Peshitta, Vulgate) in biblical textual criticism remains a significant one because, in contrast to the manuscripts from the Dead Sea, these ancient versions are complete rather than fragmentary. The LXX version has particular value in that certain books in the corpus were translated before many of the Qumran scrolls were copied; furthermore, they were produced in the Jewish diaspora in Egypt. Thus, they could in theory reflect textual traditions varying from the мт. ${ }^{2}$ At the same time, all versions are translations, and therefore at one remove from the Hebrew text. This inevitably limits their usefulness for text-critical purposes.

To use the Lxx in textual criticism of the Hebrew Bible entails reconstruction of the underlying Hebrew of the translators, a technique referred to as retroversion. Retroversion has to be based on systematic study of the tendencies of individual translators in rendering Hebrew. ${ }^{3}$ Statistical study of renderings in different books of the LXx Pentateuch was developed from the 1950s by the Finnish school, aided by the critical editing of the text by Rahlfs and the Göttingen Unternehmen. This was a significant step in this regard as it avoided

1 Alison Salvesen, "The Role of Aquila, Symmachus and Theodotion in Modern Commentaries on the Bible," in Let Us Go Up to Zion: Essays in Honour of H.G.M. Williamson on the Occasion of His 65th Birthday, ed. Ian Provan and Mark Boda (Leiden: Brill, 2012), 95-112.

2 See the clear exposition of the challenges of using the versions in Emanuel Tov, Textual Criticism of the Hebrew Bible, 3rd ed., rev. and exp. (Minneapolis: Fortress Press, 2012), $115^{-117}$.

3 The view of Anneli Aejmelaeus back in 1989, that the widely used term "translation technique" is unhelpful since the work of the LXX translators is "characterized by intuition and spontaneity more than conscious deliberation and technique," is still a valid one; "Translation Technique and the Intention of the Translators," in On the Trail of the Septuagint Translators: Collected Essays, rev. and exp., Свет 50 (Leuven: Peeters, 2007), 6o. See also the essay from 1998 in the same volume, "What we talk about when we talk about translation technique," $205^{-222}$, which argues for a rounded approach combining linguistic, statistical, and theological study. 
the more impressionistic or "cherry-picking" approach of older scholarship to the texts. The advent of computers enabled the alignment of the Hebrew and Greek texts for comparison-the cATss project. ${ }^{4}$ Although the categorisation of individual books as "literal" or "free" is too broad to be very helpful, ${ }^{5}$ clearly some books are less amenable to isomorphic alignment or statistical analysis than others. Their unpredictable renderings are often ascribed to lack of competence in Hebrew or to exegetical interference, sometimes both. It is only recently that LXX scholars have looked to the field of modern Translation Studies, especially Gideon Toury's Descriptive Translation Studies (DTS). Such approaches provide insights into the apparent "deviations" from more obvious renderings of the Hebrew text, to ascertain which may be attributable to variants in the Vorlage and which are due to either exegesis or "transformations" required by the process of translation itself. ${ }^{6}$ One of the pioneering studies in this respect is that of Theo A.W. van der Louw's Transformations in the Septuagint, which takes soundings from chapters from three different LXX booksGen 2, Isa 1, and Prov 6.

A particular contribution of modern Translation Studies to Septuagint studies is to provide a more sympathetic perspective on the translators' negotiation of difficult texts by taking seriously the overall effect of the rendering. One of the many contributions the field of Translation Studies offers to biblical scholars is to remind us that the original text is itself polyvalent, especially in the case of poetry. ${ }^{7}$ It emphasises both the possibility and legitimacy of different

4 Computer Assisted Tools for Septuagint/Scriptural Study.

5 For an early and nuanced discussion of the issues of categorising translations, see James Barr, The Typology of Literalism in Ancient Biblical Translations, MSU 15 (Göttingen: Vandenhoeck \& Ruprecht, 1979).

6 Theo A.W. van der Louw, Transformations in the Septuagint: Towards an Interaction of Septuagint Studies and Translation Studies, СЕ BT 47 (Leuven: Peeters, 2007). Responding to James Barr's claim that "freedom in translation is not a tangible method, so suitably to be grasped and comprehended" (Barr, Typology of Literalism, 7), Van der Louw counters that one purpose of his own study is "to show that 'free renderings' can be grasped and comprehended. Although transformations were not always employed consistently, they often have a logic in their own right"; Transformations, 9. A more recent application of DTs to Septuagint Studies is the monograph by Cameron Boyd-Taylor, Reading between the Lines: The Interlinear Paradigm for Septuagint Studies, BTs 8 (Leuven: Peeters, 2011), and especially his analysis of oG Job 41:1726 from the perspective of DTS (393-429) and descriptive profile of the book in terms of its translational norms and acceptability (425).

7 See Matthew Reynolds, The Poetry of Translation: From Chaucer and Petrarch to Homer and Logue (Oxford: Oxford University Press, 2011), 22, who insists on "the finally ungraspable nature of the literary text" because of its own multiple meanings even before any attempt at translation is made, and the danger of "a recurrent line of argument which conjures up a fantasy of perfect translation - of a work that is miraculously the same as its source despite 
renderings, shaped by the expectations of the target readership, as well as the personal choices and education of the translator. This leads us to a better appreciation of the translated books of the Lxx corpus as multidimensional cultural artefacts, rather than primarily sources for us to plunder for text-critical purposes or to criticise when they do not conform to our own expectations of a competent rendering of the Hebrew. ${ }^{8}$ Too often in biblical scholarship one still encounters the phrase, "the meaning of the Hebrew," as if this was obvious and unambiguous. Such attitudes also overlook the fact that our own perceptions of the text's meaning have been shaped by two millennia of scholarship and translations.

The Old Greek (OG) translations clearly became self-standing Greek texts very shortly after their creation, even if some could be used as cribs to the Hebrew for a few readers. Even in the case of books we regard as less close to the details and order of the Hebrew wording (such as LXx Isaiah, LXx Proverbs, and $\mathrm{OG}$ Job), their readers would have accepted that they were faithful representations of the overall message to the present generation in its own cultural context. $^{9}$

existing in the changed circumstances of a different language and culture." Lawrence Venuti makes a similar point: "The source text is never accessible in some direct, unmediated manner; it is always already mediated, whether it is read in the source language or translated into the receiving language"; The Translation Studies Reader, 3rd ed. (London: Routledge, 2012), 497 .

8 As an example of a now outdated attitude towards LXx Isaiah, see the remarks of R.R. Ottley in a study that is in other respects still valuable: 'The translators' mistakes in reading (however ample their excuse) are so numerous, ranging in their effect from minute points to the wreck of whole sentences, that their view cannot carry weight as to the real Hebrew text of their day"; The Book of Isaiah according to the Septuagint (Codex Alexandrinus) I. Introduction and Translation with a Parallel Version from the Hebrew (London: C.J. Clay, 1904), viii.

9 In this regard, see the illuminating discussion by Lawrence Venuti of "instrumental" versus "hermeneutic" models of translation; "Genealogies of Translation Theory:Jerome," in Translation Studies Reader, 483-502. The instrumental model treats translation as "the reproduction or transfer of an invariant which the source's text contains or causes, typically described as its form, its meaning, or its effect," while the hermeneutic model "treats translation as an interpretation of the source text whose form, meaning, and effect are seen as variable, subject to inevitable transformation during the translating process"; "Genealogies," 483. "In the hermeneutic model, any correspondence is partial and contingent: partial because it is incomplete in recreating the source text and slanted towards the receiving language and culture; contingent because it is fixed by one among other possible interpretations, each of which establishes a criterion of accuracy that varies among receiving cultural constituencies, social situations, and historical moments"; "Genealogies," 484. Venuti advocates the hermeneutic model as "more sophisticated ... comprehensive ... ethical," (485). 
However, even if we can acknowledge the renderings of "freer" LXX translations as both theologically meaningful and possessing literary merit for their early readers, in our role as textual critics we may nevertheless feel frustration at these books' apparent lack of utility in witnessing to their Hebrew Vorlage. Greek Job is particularly difficult. The lengthy Hebrew text of Job is poetic and contains many hapax legomena. Unvocalised and perhaps lacking an established reading tradition (since it was neither part of the Torah nor the Prophets), it must have presented a considerable challenge to the translator, who condensed, omitted, and embellished the content in order to produce a rendering acceptable within his community—as demonstrated by by Marieke Dhont in her recent monograph. ${ }^{10}$

The apparently "missing" stanzas ${ }^{11}$ in $\mathrm{OG} \mathrm{Job}$ vis à vis the Hebrew were later supplied by Origen in his Hexapla from a later and more isomorphic rendering, probably that of Theodotion. ${ }^{12}$ The resulting clash of translational styles in

10 Marieke Dhont, Style and Context of Old Greek Job, JSJSup 183 (Leiden: Brill, 2018). She applies the Polysystem Theory developed by Itamar Even-Zohar to oG Job. This theory views a translation as part of the larger cultural context, rather than as a text in isolation from other works and a social setting. On the challenges of cross-cultural translation, see Lawrence Venuti, The Scandals of Translation: Towards an Ethics of Difference (London: Routledge, 1998), esp. 99-102 concerning the impact of cultural presuppositions on how Homer's English translators have rendered poetic form and dealt with problematic issues such as Achilles' "unmanly" tears.

11 Omission and abridgement are not necessarily signs of lack of comprehension. It should not be ruled out that, in the case of "freer" Lxx translations, the translator had an eye to what would work in the target language and culture, and was also prepared to leave out what he considered redundant or unnecessary. In modern literary translations it is not uncommon for sentences or sections to be left out of the translation, often for commercial reasons: the translator or publisher fears that the translated book will be too long, or not appreciated in its new context. An example would be Hans Fallada's long novel Wolf unter Wölfen, published in 1937, whose original English translator Philip Owens heavily abridged the book; Wolf Among Wolves (London: Putnam, 1938). The "missing" material has since been restored by Thorsten Carstensen and Nicholas Jacobs in the 2010 edition published by Melville House. Carstensen explains in an afterword that the motivation behind many of Owens's earlier omissions seems to have been his judgment that the sections in question were too focused on the inner motivations of the characters and did not advance the plot. Ironically, some reviewers have since expressed a preference for the 1938 abridged version of the novel.

12 For the source of the asterised lines in Job, see the invaluable study of Peter J. Gentry, The Asterisked Material in Greek Job, scs 38 (Atlanta: Scholars Press, 1995). He concludes that this material dates to the early first century CE and is to be identified with the version of Theodotion for Job known to Origen, though Gentry leaves open the question of how it relates to Theodotion Daniel or to Theodotion in other books; Asterisked Material, 494499 . 
the ecclesiastical text of Job has been termed "a genetic monstrosity hybridized from apples and oranges" by Peter Gentry. ${ }^{13}$

As in other books, Aquila and Sym. also produced their own versions of Hebrew Job, which were culled from Origen's Hexapla and preserved only very fragmentarily in the margins of manuscripts or in patristic commentaries. ${ }^{14}$ The textual critic can easily employ the readings of Theodotion and Aquila in Job, owing to their isomorphic approach and tendency to standardise renderings (or hazard "etymological" ones, in the case of hapaxes), since these features aid retroversion to a presumed Vorlage.

In the case of the readings to Job from Sym., both the brevity of the preserved readings and the unpredictability of his translational choices make the task of retroversion a hard one. Yet his version can still yield interesting results for textual criticism.

\section{3}

Examples from Symmachus in the Book of Job ${ }^{15}$

The following examples from what remains of Sym.'s renderings of Job demonstrate first of all—as in other books - his confident use of educated Greek and his desire to remain closer to the Hebrew text than OG Job without resorting to isomorphism. ${ }^{16}$ In spite of the difficulties Sym.'s style of rendering presents to retroversion and thus to using his version for textual criticism of Hebrew Job, in a few instances it is clear that Sym. knew of a different reading tradition from the $\mathrm{MT}$, and in one or two, he recognised a slightly different consonantal text.

13 Peter J. Gentry, "The Place of Theodotion-Job in the Textual History of the Septuagint," in Origen's Hexapla and Fragments, ed. Alison Salvesen, TSAJ $5^{8}$ (Tübingen: Mohr Siebeck, 1998), 199.

14 John Meade's fresh edition of the Hexaplaric material to Job chs. 22-42 supersedes Frederick Field's edition of this material in his Origenis Hexaplorum quae supersunt sive Veterum interpretum Graecorum in totum Vetus Testamentum fragmenta, 2 vols (Oxford: Clarendon Press, 1875), though it is still worth consulting Field for his retroversions and erudite comments; John D. Meade, A Critical Edition of the Hexaplaric Fragments of Job 22-42, Origen's Hexapla: A Critical Edition of the Extant Fragments (Leuven: Peeters, 2020). My thanks to Prof. Meade for supplying copy of his work in advance of publication.

15 The examples are taken from the Göttingen edition of Job-Joseph Ziegler, Septuaginta. Vetus Testamentum Graecum Auctoritate Academiae Scientiarum Gottingensis editum XI.4: Iob (Göttingen: Vandenhoeck \& Ruprecht, 1982), and see especially Ziegler's notes on the sources for the Three in Job (151-161).

16 Ideally one should employ a similar analysis to that of Theo van der Louw, but the fragmentary state of Sym.'s readings hinders systematic categorisation of the different types of transformation. 
The first three examples note some instances where Sym. represents the Hebrew faithfully without resorting to isomorphism or stereotyping, and yet produces a rendering that differs from the oG's own relatively free handling of its Vorlage.

\section{Stylistic Improvement of Syntax and Vocabulary}

Job 2:11fg

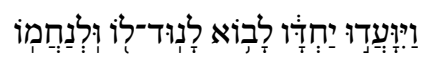

"They arranged together to come to commiserate with him and to comfort him."

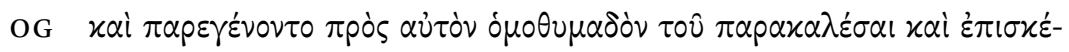
$\psi \alpha \sigma \theta \alpha \iota$ aĩóv

"And they came to him with one accord to comfort and show concern about him."

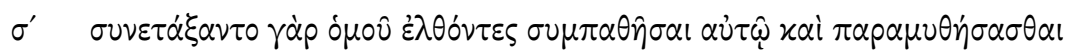

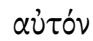

Sym. "For they arranged, having come together, to sympathise with him and console him."

Dhont notes that the use of the articular infinitive is a feature of Koine, as is also the meaning of $\pi \alpha \rho \alpha \varkappa \alpha \lambda \varepsilon \dot{\varepsilon} \omega$ as "to comfort."17 In non-biblical Greek $\dot{\pi} \pi \sigma x \dot{\varepsilon}-$ $\pi \tau o \mu \alpha$ c can have the sense of visiting the sick, ${ }^{18}$ so is used appropriately in this

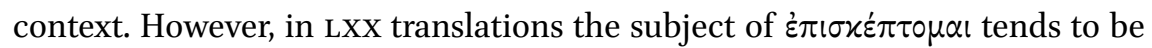
God rather than humans; he "visits" them with benevolent attention.

In contrast to the oG, Sym. uses ráp instead of $x \alpha$ i, and an aorist participle for the first of three Hebrew infinitive constructs. Sym. also uses $\delta \mu o v$, which is not used in the translated books of the Lxx corpus apart from one place in an asterised addition to Job (34:29), but occurs in the non-translated works $(2,3,4 \text { Maccabees; Wis 7:11 })^{19}$ and in other preserved readings from Sym. ${ }^{20} \mathrm{He}$

17 Dhont, Style and Context, 123, 125, citing Geoffrey Horrocks, Greek: A History of the Language and its Speakers, 2nd ed. (West Sussex: John Wiley \& Sons, 2010), 94, and John A.L. Lee, A Lexical Study of the Septuagint Version of the Pentateuch, scs 14 (Atlanta: Scholars Press, 1983), 83 .

18 See references in BDAG ad loc., § 2.

19 My thanks to Jan Joosten for pointing this out.

20 According to Hatch and Redpath, at Gen 3:22; 2 Kgdms 2:13, 15; Job 3:18; 24:4; Ps 37:38 (36:38 
avoids the articular infinitive. The verbs he employs here are uncommon in

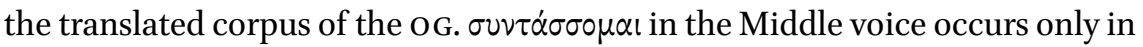
1Esd 2:15; OG Dan 11:23, and Theodotion Sus 14, the last of which corresponds closely in sense to Sym.'s use here in Job 2:11. $\sigma \nu \mu \pi \alpha \theta \varepsilon \dot{\varepsilon} \omega$ occurs only once, in

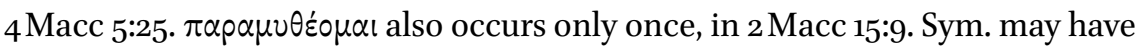

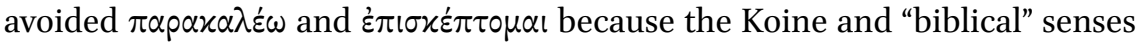
they had acquired did not in his view match the context. He preferred more literary-sounding verbs in this instance.

\subsection{Sym. Closer to the Hebrew than og but Smoother than Theodotion and Aquila}

Job 1:16b

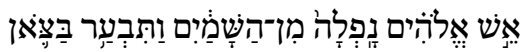

"Fire of God/a mighty fire fell from the sky and burned up the flock."

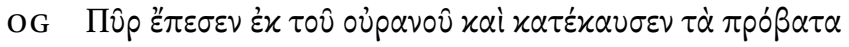

"Fire fell from the sky and burned up the sheep."

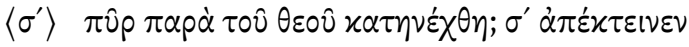

Sym. "Fire from God descended ... it slew ..."

The oG's "fire from heaven/the sky" is discussed by Dhont, who observes that this is an imprecise rendering influenced by similar phrases in other LXX books. ${ }^{21}$ Aquila and Theodotion are recorded as having the predictably literal rendering $\pi \hat{v} \rho$ $\theta \varepsilon \circ \hat{v}$, "fire of God." Sym. is also closer to the Hebrew in this respect, but provides a smoother and less Hebraic rendering by avoiding a

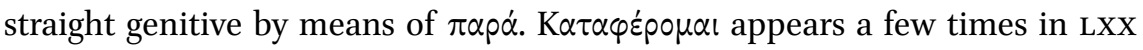

LXX); 48:5 (47:5 LXX); 49:3, 11 (48:3, 11 LXX); 62:10 (61:10 LXX); 74:6 (73:6 LXX); 122:3 (121:3 LXX); 141:10 (140:10 LXX); Isa 52:9; 6o:13; Jer 6:11; 10:8; 46:12 (26:12 LXX).

21 Dhont, Style and Context, 13-14 and n. 20. Other scholars have suggested that the omission of "of God" was theologically motivated: Gillis Gerleman, Studies in the Septuagint I: Book of Job, Lunds Universitets Arsskrift N.F. Avd. 1, Band 43. No. 2 (Lund: Gleerup, 1946), 58; Donald H. Gard, The Exegetical Method of the Greek Translator of the Book of Job, JBLMs 8 (Atlanta: SBL Press, 1952), 61; Martina Kepper and Markus Witte, "Job. Das Buch Ijob, Hiob," in Septuaginta Deutsch. Erläuterungen und Kommentare, ed. M. Karrer and W. Kraus (Stuttgart: Deutsche Bibelgesellschaft, 2011), 2:2069. Yet Homer Heater notes that the word "God" may not have been in the oG's Vorlage, and is absent in some Hebrew manuscripts of 2 Kgs 1:12; A Septuagint Translation Technique in the Book of Job, СвQмS 11 (Atlanta: SBL Press, 1982), 20-21. 
translated books, usually in comparisons of water or hail pouring down (2 Sam 14:14; Isa 17:13; 28:2; Ezek 47:2; Mic 1:4).

\subsection{Higher Register Lexical Choice}

Job 1:20a

"And Job stood up and tore his robe"

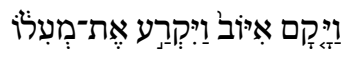

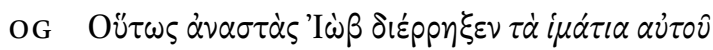

"Thus having stood up, Job tore apart his clothes"

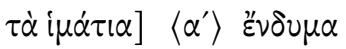

$$
\begin{aligned}
& \sigma^{\prime} \quad \dot{\varepsilon} \varphi \varepsilon \sigma \tau p^{\prime} \delta \alpha 248\left(\operatorname{sub} \alpha^{\prime}\right) \\
& \theta^{\prime} \quad \tau \dot{v} v \dot{\varepsilon} \pi \varepsilon v \delta \dot{\tau} \tau \eta \nu
\end{aligned}
$$

מעיל is not a standard item piece of clothing in the Hebrew Bible. It is associated with the high priest in Exod 38 and 39, and Lev 8. It is worn by Samuel as a child, a prophet, and a ghost; by Saul and Jonathan; by virgin princesses (2 Sam 13:8); by princes (Ezek 26:16); by David bringing up the ark (1Chron 15:27); by Ezra the priest (Ezra 9:3, 5) and by Job's high-ranking visitors (Job 2:12) as well as by Job himself here. It is rendered by a variety of Greek words in the LXX corpus, including $\tau \dot{\alpha} i \mu \alpha \dot{\alpha} \iota \alpha$ as it is here, though this is a term without special connotations. In this verse both Theodotion and Aquila employ their standard equivalents for מעיל: Theodotion uses غ̇ $\pi \varepsilon v \delta \dot{u} \tau n$ "robe," as in 2 Sam 13:8, and

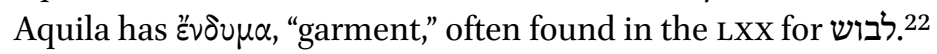

However, here Sym. has $\dot{\varepsilon} \varphi \varepsilon \sigma \tau p i \varsigma$, a word that does not appear in the LXX, NT, Josephus, or Philo. According to LSJ, ह̇ $\varphi \varepsilon \sigma \tau p i ́ s$ refers in Xenophon to an upper garment, and in Athenaeus to a philosopher's mantle, though in Plutarch to a soldier's cloak. Whether Sym. intended to indicate something about Job's social standing by the use of this term is unclear. The historian Herodian, a contemporary of Sym., uses the term three times, of fine clothes and of praetorians wearing civilian dress (Ab Excessu Divi Marci 4.2.3; 7.11, 2, 3), so it was not confined to elite attire. One of the Suda's lexical comments suggests the word was sometimes associated with afflictions. ${ }^{23}$

\footnotetext{
22 See Field, Origenis Hexaplorum fragmenta ad loc., and Ziegler's apparatus for the attributions in the witnesses to Aquila and Sym.

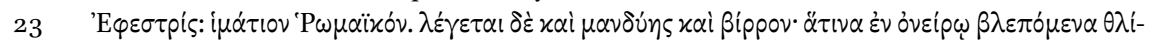

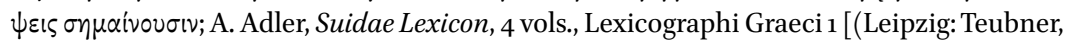
1928-1935), accessed online at Thesaurus Linguae Graecae.
} 


\subsection{The Case of}

Sym.'s treatment of תפלה may be a theological manoeuvre. He also transforms verb + noun to verb only.

Job 1:22c

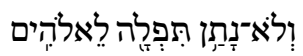

The precise meaning of the word sְְִָּה is hard to determine here, and scholars and translations differ a great deal: ${ }^{24}$

\begin{tabular}{|c|c|}
\hline NRSV & "or charge God with wrong-doing;" \\
\hline NJPS & "or cast reproach upon God" \\
\hline ASV & "nor charged God foolishly;" \\
\hline NEB & "nor charged God with unreason." \\
\hline OG & 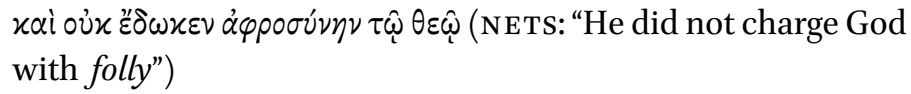 \\
\hline$\sigma^{\prime}$ & 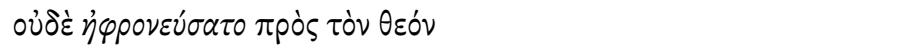 \\
\hline Vulgate & neque stultum quid contra Deum locutus est \\
\hline Peshitta & "nor did he blaspheme [ה.入] against God." \\
\hline
\end{tabular}

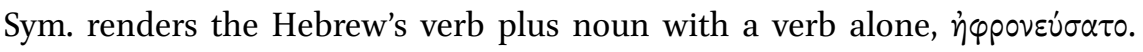
Though this evidently reflects a similar understanding to the oG of "foolishness," the overall sense is "nor did he act foolishly towards God," which is rather different from the OG. Presumably the foolish action Sym. envisaged would have been for Job to blame God for his troubles: compare the reading of the 'Hebrew' ( $\left.\dot{\varepsilon} \beta \rho^{\prime}\right)$ version preserved in the catena tradition: o ${ }^{\prime} x \dot{\varepsilon} \mu \varepsilon \mu \psi \alpha \tau 0 \tau \hat{\emptyset}$ $\theta \varepsilon \omega \hat{\omega}$, "he did not blame God/find fault with God." However, Sym.'s verb $\alpha \varphi p o-$

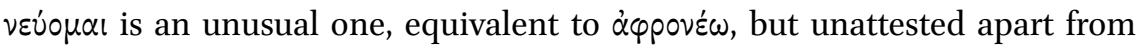
LXX Jer 10:21 (for niphal of בער), and Sym. 1Kgdms 13:13; ${ }^{25} 26: 21$ for niphal סכל.

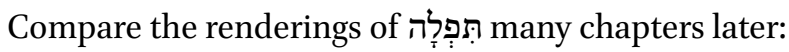

24 See $D C H$ 8:665, for possible meanings of תפל (1. Tastelessness, unseemliness; 2. perhaps curse, blasphemy") and suggested emendations; also 4Q230 1, 2 and 4Q525 14 II, 28 for תופלה, "insolence." The discussion in the philological notes of S.R. Driver and G.B. Gray remains helpful; A Critical and Exegetical Commentary on the Book of Job, together with a New Translation, ICC (Edinburgh: T\&T Clark, 1921) 2:10-11.

25 One of the two manuscripts with this reading corrects it to $\eta \varphi p o v \eta \sigma \alpha \varsigma$ derived from the more familiar form $\dot{\alpha} \varphi p o v \varepsilon \dot{\omega} \omega$. 


\section{Job 24:12c}

"Shall God not attribute unseemliness?"

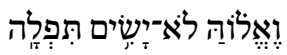

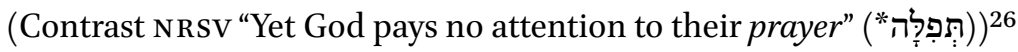

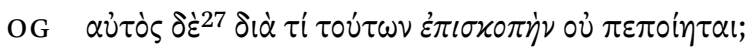

"yet for what reason has he not carried out visitation on these people?"

(Contrast NETs "and he, why has he not paid these a visit?")

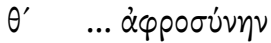

“... senselessness"

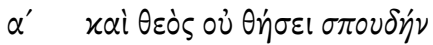

"and shall God not make haste?"

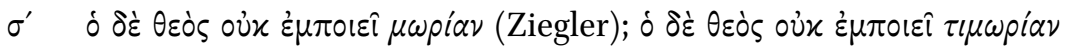
(Meade)

"yet God does not cause folly" on "yet God does not carry out punishment"

Here the OG's rendering is quite unexpected. It seems to be a contextual rendering within the broader passage in which Job is complaining that the wicked do terrible things but God does not punish them. ${ }^{28}$

We have only a single word here from Theodotion, but he apparently picks

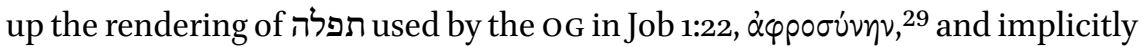
corrects the oG in the present verse.

26 Hans Strauß, Hiob: Kapitel 19,1-42,17, BKAT XVI/2 (Neukirchen-Vluyn; Neukirchener Verlag, 2000), 86, notes that two Hebrew manuscripts as well as the Peshitta have which he believes to be the original reading (cf. B HS note on Job 24:12c "frt l c 2 Mss S

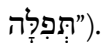

27 See Claude Cox, "Tying It All Together: The Use of Particles in Old Greek Job," вIOscs 38 (2005): 41-54, on the OG translator's frequent use of $\delta \dot{\varepsilon}$ (along with other particles) to clarify what he considered to be the flow of the text.

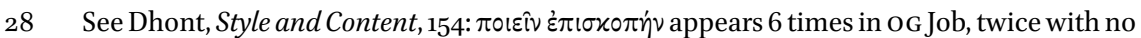
formal correspondence. It is not a construction found in Classical Greek or papyri, though the word $\dot{\varepsilon} \pi 1 \sigma$ ห० $\eta^{\prime}$ on its own is Koine. Cf. also og Isa 23:17 and Prov 29:13. God is always the subject of this construction.

29 The only witness to Theodotion's and Aquila's readings here is the Syrohexapla, but they are easily reconstructed in Greek. 
The original form of Sym.'s reading here is debated. For Job 24:12c Field gives

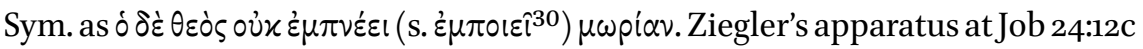

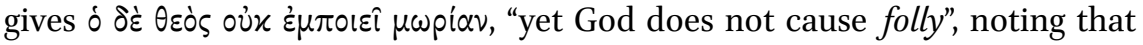
manuscript 250 places $\tau \iota$ before $\mu \omega$ piav and the Catena group minus 250 have غ̇ $\mu \pi \nu \varepsilon \dot{\varepsilon}$. However, John Meade has checked the Kollationen of hexaplaric fragments made by Ursula and Dieter Hagedorn and notes that manuscripts $25^{\circ}$ and 3005 both have $\tau \mu \omega \omega$ pi $\alpha \nu$ (creating a rhetorical question, "Yet does God not carry out vengeance?"). Meade cites Jerome's et Deus inultum abire non patitur in support of this reading, and argues that Sym. understood תפלה here as derived from piel פלל, meaning "to pronounce judgment."31

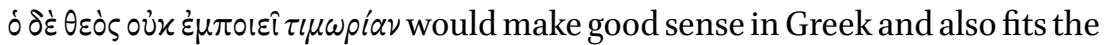
context. However, it creates a mismatch between how Sym. understands in Job 1:22 (as "foolishness") and in 24:12 (as "retribution"). A consistent under-

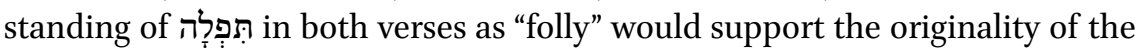

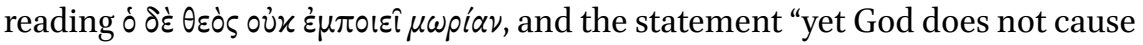
folly." In context the rendering would imply that the wicked are responsible for their own actions: God does not force them to act foolishly in this way. ${ }^{32}$ However, given Sym.'s unpredictability in rendering, the other reading (preferred by Meade) is also possible.

\subsection{Treatment of Metaphors}

Metaphors in poetry are often a challenge for translators. They may be rendered by using a simile to clarify the sense, as Sym. does here.

\section{Job 24:16}

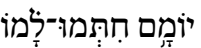

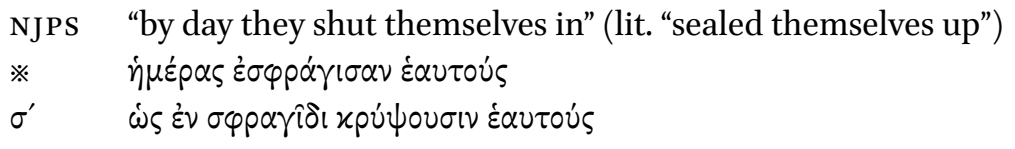

The oG does not provide a rendering of this verse. The translation supplied by

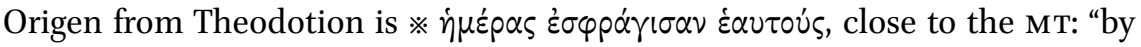

\footnotetext{
30 On the basis of Syh דרמה.

31 Meade, Critical Edition, 62-63.

32 According to the Syrohexapla as retroverted by Field (Origenis Hexaplorum fragmenta,

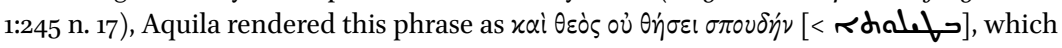
Field compared with the Harklean version at Mark 6:25. Field believed this reconstructed reading was probably to be understood in the sense, "and shall God not show diligence?" However, where the LXX and Aquila use $\sigma \pi \circ v \delta \eta$, it seems always to be in the sense of "haste" rather than "care."
} 
day they sealed themselves up" (NETS). Sym. prefers to change it into a simile:

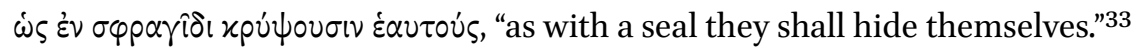

\subsection{Building on Earlier Renderings}

Though Sym. often goes his own way, especially against Aquila's isomorphism and standardised equivalents, he may also build on the precedent of earlier renderings.

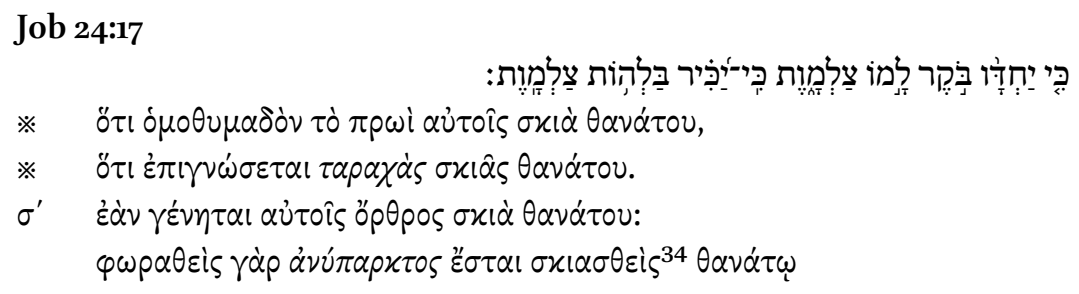

In a continuation of the passage describing the attitude of the wicked, this rather opaque Hebrew verse is rendered interpretatively by NRSV as "For deep darkness is morning to all of them; for they are friends with the terrors of deep darkness;" and perhaps more effectively by NJPS as "For all of them morning is darkness; It is then that they discern the terror of darkness."

There is no og translation for this verse (or for several around it), since the translator jumped straight to the curse in 24:18c. However, the asterised Theodotion text (cited above) supplies a rendering that NETS understands to mean "because with one accord the morning is death's shadow to them, because he will recognise the troubles of death's shadow."

Sym.'s rendering does not seem very close to the Hebrew; "If dawn comes to them, [it is] death's shadow: for once discovered, it will be non-existent, over-

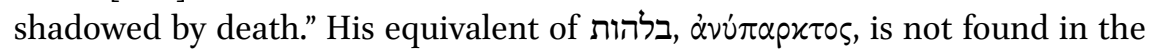
NT, LXX, or Josephus, but does occur five times in Philo. ${ }^{35}$ The rendering is not unprecedented: it is evidently influenced by renderings in LXx Ezekiel where בלהות occurs followed by references to future nonexistence (Ezek 26:21 xai oủx

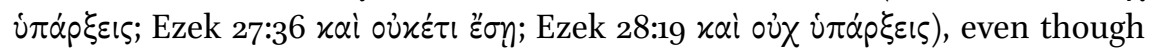

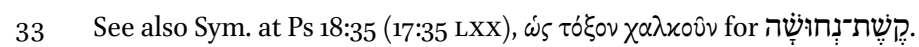

34 Field has $\beta \iota \alpha \sigma \varepsilon i \varsigma$ here, but there is no support in Ziegler's apparatus for this reading. Meade, Critical Edition, also gives $\sigma \varkappa\llcorner\sigma \theta \varepsilon i \zeta(67)$. Field's note (Origenis Hexaplorum fragmenta, vol. II:46 n. 23) underlines his dependence on earlier scholars rather than familiarity with the manuscript and Catena sources in this case.

35 Mut. 36; Spec. 3:45; Prob. 72; Aet. 5; 105. The word's philosophical overtones are clear from its frequency in Sextus Empiricus ( 2 nd-3rd century CE) and by patristic writers, especially on the subject of creation. 
בלהות itself is translated in each of these instances as $\dot{\alpha} \pi \dot{\omega} \lambda \varepsilon i \alpha$, "destruction." בל as בלהות Aquila is the likely source for the equivalence, based on construing "היות* "not-being." Thus while the og apparently rendered בלהות at Job 18:14 as $\alpha \nu \alpha \gamma \gamma \varkappa \eta$, "compulsion," Aquila used the noun $\alpha \nu v \pi \alpha p \xi i \alpha$, "non-existence."36 In a further occurrence of בלהות, Job 27:20 where the OG has ai óoival, Aquila and Sym. are both recorded as rendering it as $\dot{\alpha} v v \pi \alpha p \xi i \alpha$.

To summarise, the association of בלהות with non-being originated with LXX Ezekiel. Using a rather ingenious etymology, Aquila used a contemporary philosophical term to render the word בלהות itself. Although Sym. does not often accept Aquila's equivalences, in this case he did, employing both the nominal form $\dot{\alpha} v v \pi \alpha \rho \xi i \alpha$ and the adjective $\dot{\alpha} v \dot{v} \pi \alpha p x \tau \circ{ }^{37}$

\subsection{Job 24:25}

In the following example consisting of two separate fragments, we see Sym.

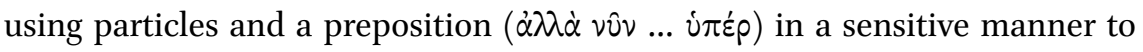
convey the apparent sense. However, he also witnesses to a non-M tradition of vocalisation.

Job 24:25

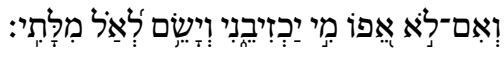

NRSV "If it is not so, who will prove me a liar, and show that there is nothing in what I say?"

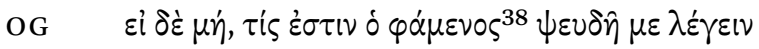

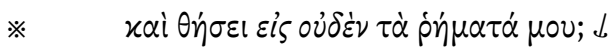

NETS "But if it is not so, who is there to say that I speak what is false

* and will he place my words as nothing?" \&

36 The earliest occurrence of the noun is in the first century вСЕ philosopher Philodemus,

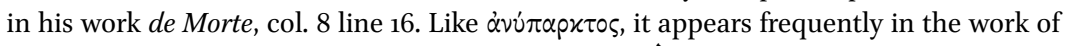
Sextus Empiricus and in patristic writers. See also בלהות in Job 18:11 (og óóvol, "pains") where Aquila's rendering has to be reconstructed from the Syrohexapla, but was probably $\alpha v v \pi \alpha \rho \xi i \alpha$. Though there is a tentative attribution of $\alpha v v \pi \alpha \rho \xi i \alpha$ to Theodotion in Field at Job 18:15 for מִבְִִּי-לו Field has a corrective note (Origenis Hexaplorum fragmenta, 2:34 n. 18), which is apparently accepted and followed by Ziegler in his edition of Job.

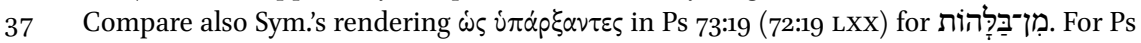

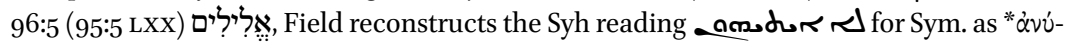
$\pi \alpha p x \tau 0 \mathrm{l}$ (Origenis Hexaplorum fragmenta, 2:253 and n. 4), but this seems unlikely both as an equivalent for the Hebrew and as representing the Syriac.

38 Martina Kepper and Markus Witte, "Hiob," in Septuaginta Deutsch 2:2101, mention Thackeray's opinion that the use of this middle participle of $\varphi \eta \mu$ i demonstrated the oG translator's familiarity with Homer. 


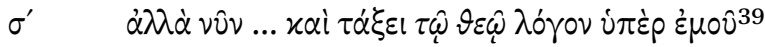
"Rather, now ... and [who] will set [before] God a word on my behalf?"

Sym. must have read the consonants as representing לְֵ לִ rather than the MT's

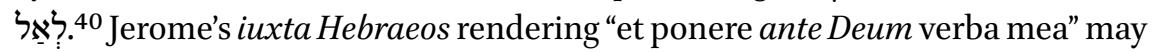
have been influenced or supported by Sym., although he may also have known of the same vocalisation independently. The Peshitta evidently also under-

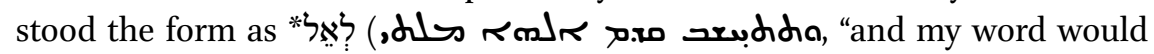
be considered before God"), demonstrating that this particular vocalisation of the Hebrew was more widely established (rather than confined to Sym.'s circle) in the late second century CE.

\subsection{Job 25:3-4}

In the following passage Sym. follows the Hebrew more closely than the oG, and possibly indulges in some wordplay.

Job 25:3-4

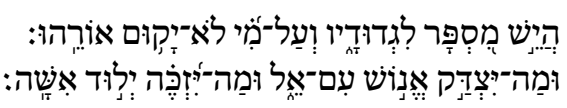

NRSV "Is there any number to his armies? Upon whom does his light not arise?

How then can a mortal be righteous before God? How can one born of woman be pure?"

In v. 3 the OG unexpectedly interprets the verse as suggesting the certainty of divine punishment for pirates (or highwaymen):

OG

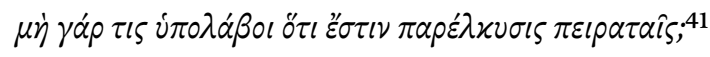

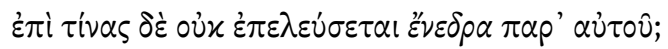

39 The reconstruction follows Meade, Critical Edition.

40 Also noted by Meade, Critical Edition, ad loc. The variant reading also occurs in some Hebrew codices cited by De Rossi; Variae lectiones Veteris Testamenti, volumen IV: Psalmi, Proverbia, Job, Daniel, Ezras, Nehemias, Chronica, seu Paralipomena (Parma: Regio, 1788), 121. I am grateful to Jan Joosten for this reference.

41 Harry M. Orlinsky interprets the oG as a statement, "let none think that there is respite

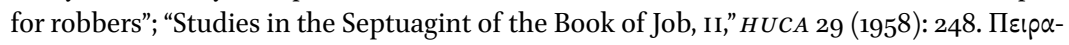

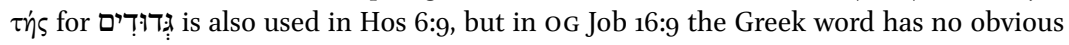

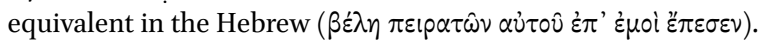




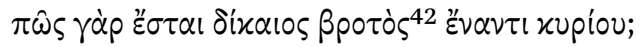

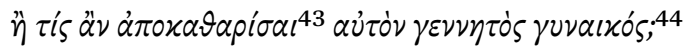

NETS "For would there be anyone who thinks there is respite for brigands? And upon whom will not come ambushes from him?

For how can a mortal be right before the Lord?

Or who, born of woman, could purify himself?"

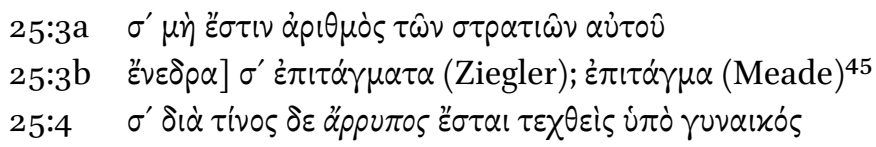

In contrast, Sym. understands 25:3a as referring to the overwhelming power of

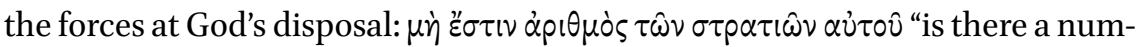

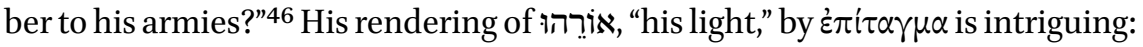
the word may denote an understanding as "command" from the supposed etymological connection of with Torah commonly found in the later Jewish revisers, ${ }^{47}$ but taking it as "detachment of troops" would link with the idea of armies in the previous line. Since we do not know how Sym. rendered the rest of the line, it is hard to be sure whether any wordplay was intended.

For v. $4 \mathrm{~b}$ we do have an entire line of Sym. preserved in the Catena tradition, "by what means shall one given birth by woman be clean?" However, the form ápputos is attested rather later than Sym.'s time, and one wonders whether this is the original form of the reading. ${ }^{48}$

42 Dhont notes that the rather poetic word ßpotós is used only in OG Job in the LXX corpus; Style and Context, 41.

43 Kepper and Witte note that this is a neologism in the LXx, found also in Tob 12:9; "Hiob," 2102.

44 See Dhont on the higher register of the OG in its use of the optative that was declining in Koine; Style and Context, 150-151.

45 Meade, Critical Edition, 74-75, argues convincingly for the singular form against the majority reading in the plural favoured by Ziegler.

46 Meade's Critical Edition prefers $\sigma \tau p \alpha \tau i \omega \hat{\nu}$ over the variant $\sigma \tau p \alpha \tau \iota \omega \tau \hat{\omega} \nu$, "soldiers", found in manuscripts $256-740$.

47 See Alison Salvesen, Symmachus in the Pentateuch, Jss Monographs (Manchester: Journal of Semitic Studies, 1991), 70, on Aquila's rendering $\varphi \omega \tau$ iלรเv for הורה in Exod 4:12, 15; 35:34; and see 173-174 on Sym.'s rendering of אורים in Deut 33:8.

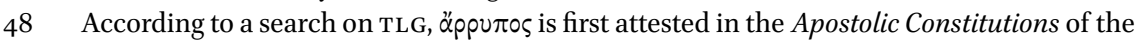

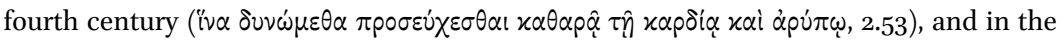

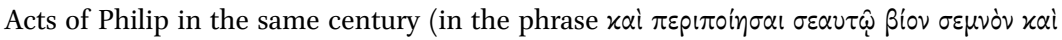

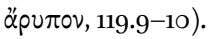




\subsection{Job $26: 5$}

This verse in Hebrew has mythological connotations which Sym. may have attempted to match in Greek.

\section{Job 26:5}

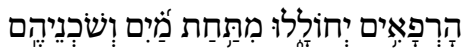

"The shades tremble below the waters, and their inhabitants."

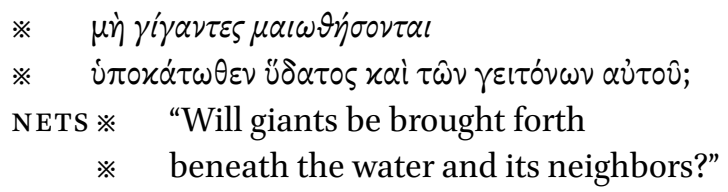

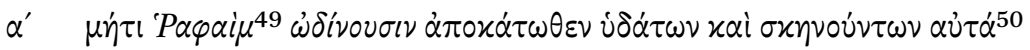
"Do Raphaim have birth pangs from below waters and the ones encamped in them?"

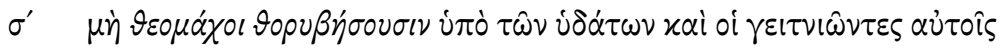
"Shall the Godfighters clamour under the waters, and those neighbouring them?"

Evidently Theodotion Job, Aquila, and Sym. all understood the line as a rhetorical question. This suggests that there was a wider tradition that took the he of the M T's definite article as an interrogative ( ${ }^{*}$ ) $) .{ }^{51}$ Theodotion Job and Aquila both associated the verb with the noun denoting labour pains, חיל.

Sym.'s $\theta$ opußnं ring at least 12 times according to Hatch and Redpath, and for a variety of Hebrew words. But the clue may lie in Eccl 7:7, where Sym. rendered יִ as as

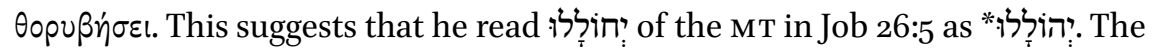
strong similarity between khet and he in square script-observable in Qumran manuscripts - was still an issue in the second century $\mathrm{CE}$, and it would be difficult to say which of the two readings was more original. ${ }^{52}$

49 See Meade, Critical Edition, 80, for a discussion of the original form of the name.

50 Field has some minor variants in Aquila's reading compared with Ziegler's apparatus (both based on Greek manuscript $252 \mathrm{Syh}$ ) and the reconstruction of Meade (Critical Edition, $80)$.

51 Cf. also the Peshitta's $<\mathrm{m}$, which often represents Hebrew interrogative he; and Targum to Job's - איפשר ד, "it is possible that ...." Thanks to Jan Joosten for noting these parallels.

$5^{2}$ Jerome's iuxta Hebraeos reading gemunt, "groan," could conceivably render either form. 
Theodotion Job's "giants" are influenced by the rendering of Rephaim in Gen 14:5; Josh 12:4, 13:12 and elsewhere (the same Greek occurs for the Nephilim of Genesis too), but Aquila prefers to transliterate what he understands as a proper name. Sym. may be "acculturating" the reference within the target language: Hans-Joachim Schoeps has argued that Sym.'s rendering here is a reference to the Greek myth found in Apollodorus (1st-2nd century CE), of the race of earth-born giants who fought the gods. ${ }^{53}$ This is possible, though it should also be noted that the same word also appears in the mouth of Gamaliel in Acts 5:39 in his warning to those opposing the followers of "the Way," where the allusion cannot be mythological!54 The related verb $\theta \varepsilon \circ \mu \alpha \chi \varepsilon \hat{\nu}$ occurs in 2 Macc 7:19 and Josephus's $c$. Ap. 1:246, 263, where they also concern human challenges to the God of the Jews. These examples evidently have no connection to Greek mythology. However, Schoeps's case is somewhat strengthened by Sym.'s use

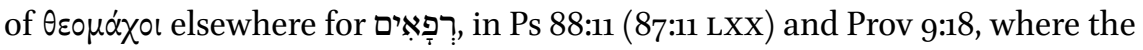
Hebrew verses speak of the underworld, and so could fit with a mythological presentation.

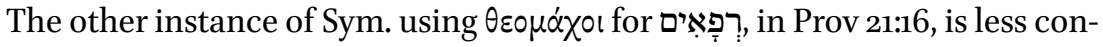
vincing as a reference to Greek myth. This is because the verse states that a person who strays from the path of understanding will end up "in the assembly of Rephaim/ $\theta \varepsilon \circ \mu \dot{\alpha} \chi \omega \nu^{\prime \prime}$ : in this case, the sense of $\theta \varepsilon \circ \mu \dot{\alpha} \chi \chi 01$ as humans who rebel against the Jewish God is more likely.

Certainly in the next example Sym. seems to reject a mythological reading:

Job 26:12-13

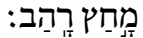

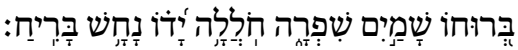

NRSV “... he struck down Rahab. By his wind the heavens were made fair; his hand pierced the fleeing serpent."

OG Ët

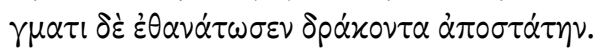

NETS "He struck down the sea-monster, (13) and heaven's bars fear him, and by decree he put to death the rebellious dragon."

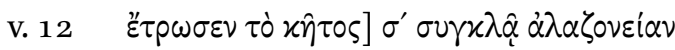

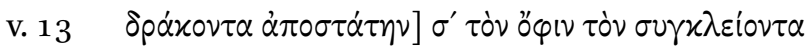

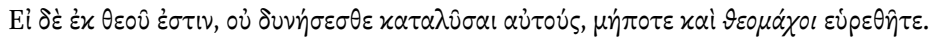


Marieke Dhont argues that OG Job regularly demythologises Leviathan and Rahab by rendering them as $x \hat{\eta} \tau \circ \varsigma$, the translation used in LXX Gen 1 of the great sea creatures made by God, and in the case of Leviathan, once as $\delta \rho \alpha \dot{x} \omega \omega{ }^{55}$

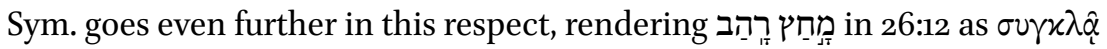
$\alpha \lambda \alpha \zeta o v \varepsilon i \alpha \nu$ "he crushes arrogance," no doubt following his usual understanding of the root רהב as referring to pride rather than the sea serpent of ancient

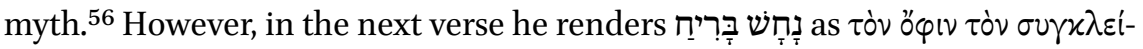

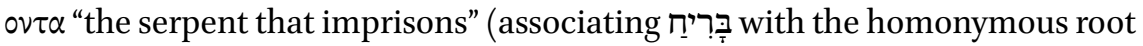
meaning "to bar"). Both the Hebrew and Sym. share a close verbal connection to Isa 27:1 prophesying God's punishment of "Leviathan the fleeing serpent,"

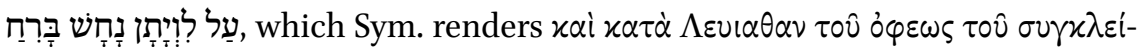

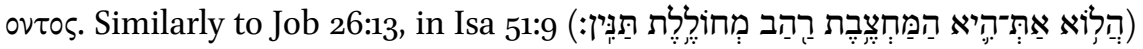
Sym. renders "Rahab" as the abstract "arrogance" again, paired with a reptilian

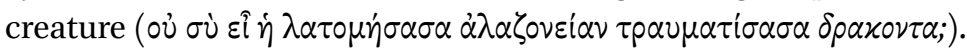

\subsection{Job 29:4}

Here is another example where Sym.'s rendering reflects a non-MT readingeither owing to a variant in his Vorlage, or to his own misreading of the consonantal text.

Job 29:4

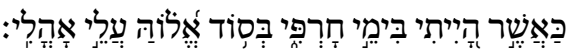

NRSV "when I was in my prime, when the friendship of God was upon my tent"

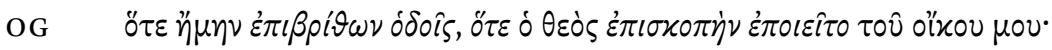

NETS "when I was pressing on my ways, when God would pay a visit to my house"

55 Job 7:18; 31:14; Isa 23:17. Dhont, Style and Context, 129-131, would disagree with Gerleman's contention that the choice of $\delta \rho \dot{\alpha} \kappa \omega \nu$ in OG Job here is a conscious mythologisation (Gerleman, Studies, 40-42). See also Boyd-Taylor, Reading Between the Lines, 418.

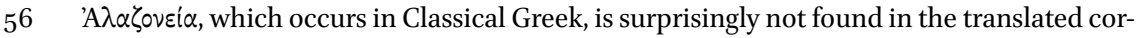

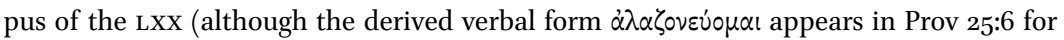

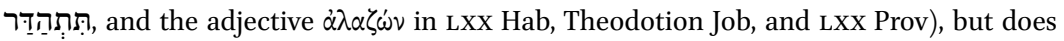
occur in the Jewish Greek compositions: 2 Macc 9:3; 15:6; 4 Macc 1:26; 2:15; 8:19; Wis 5:8; 17:7. It is common in Philo, and appears in both Josephus and the NT. Sym. usually under-

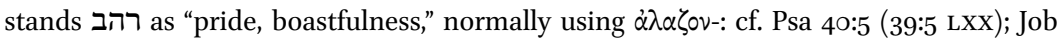
9:13. In Psa 87:4 (86:4 LXx) he renders with i $\pi \varepsilon p \eta \varphi \alpha v i \alpha$. Yet at Isa 30:7 Sym. has $\tau \alpha \rho \alpha \chi \eta^{\prime}$ (o G $\mu \alpha \tau \alpha i \alpha)$ for רהב. 


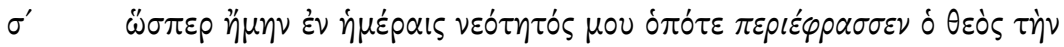
$\sigma x \eta \nu \eta \dot{\nu} \mu \sigma_{0}$

The sense of the first half of the verse in Hebrew is only clear from the context: Job is evidently looking back to a better period of his life, when God was with him. The literal sense of the word חָרִִּּ is debated, since there are two homonymous roots חרף. $D C H$ (3:320) lists this verse under the sense "reproach," implying that Job is reflecting back to the days of his youth, presumably seen as a period of foolish behaviour! ${ }^{17}$ Another possibility is "autumn," i.e. prime, a period of personal fruitfulness, as $B D B(358 \mathrm{a})$ has it; c.f. HALOT also associates it with חרֶר "winter" but via the sense of "early time," hence "youth." Either way, most translators identify the expression as a metaphor.

The notable lack of formal correspondence between the Hebrew and the OG in this verse is observed by Dhont. ${ }^{58}$ The og misses the metaphor in the first half of the line, and though סוֹ is common enough in the Hebrew Bible, and usually refers to being in someone's friendship circle or confidence, many LXX translators struggle to give it a consistent sense or rendering. ${ }^{59}$ OG Job is no

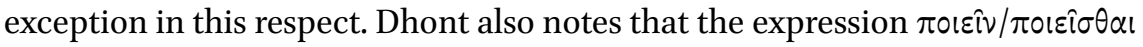

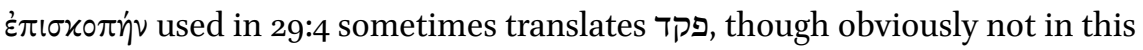
case. ${ }^{60}$

Sym. clarifies the metaphor in the first half of the line by rendering $\omega \sigma \pi \varepsilon p$

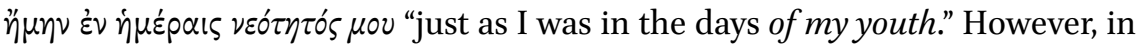
the second part of the line, Sym.'s verb $\pi \varepsilon p 1 \varepsilon \dot{\varphi} \varphi \alpha \sigma \sigma \varepsilon v$ "when God used to fence my tent about," indicates that he read the form as בסוך, an infinitive construct with bet (סוך is an alternative form of שוך, "to hedge around.") This reading gives a much better sense, and it is supported not only by the Peshitta here (שה ד>N: שוך does occur in the MT:

Job 1:10

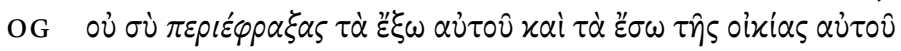

57 Peshitta Job 29:4 does render literally, as .حשכת, טمזָ, "in the days of my disgrace" (evidently חרף I), but thereby creates a problem with the overall sense of the passage.

58 Dhont, Style and Context, 154.

59 Despite Gen 49:6 where it is accurately translated as $\beta$ ou $\lambda \dot{\eta}$.

6o Gard, Exegetical Method, 14, remarks on the oG's use of ह̇ $\pi 1 \sigma x \circ \pi \eta$ twice in Job 34:9 to denote God's "oversight" of a man, for Hebrew that the translator considered problematic theologically. However, the difficulty of the Hebrew here may have caused the translator to see one of his preferred themes in this verse. 


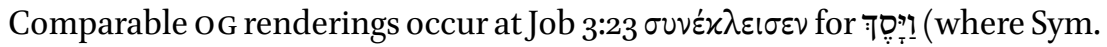

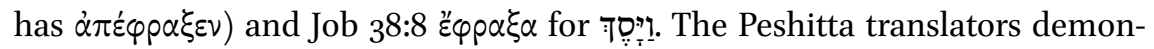
strate a comparable approach to these similar roots in their employment of

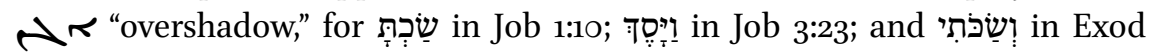
$33: 22 .{ }^{61}$

\section{$4 \quad$ Conclusion}

Sym. in Job (as elsewhere) provides good examples of van der Louw's observation, "Behind each transformation stands a literal rendering that has been rejected,"62 a literal rendering that we may sometimes see in a corresponding fragment of Theodotion or Aquila (e.g. Job 1:16b; 24:17). Yet although both oG Job and Sym. have a clear eye for high level Greek and syntactic naturalness, Sym.'s own transformations are not the same as those of og Job. This situation does more than exemplify the truism that translational freedom can take many paths: where Sym.'s approach differs from oG Job — apart from reflecting the influence of non-Koine Greek (e.g. Job 1:20a; 2:11fg), and a different theological perspective (e.g. Job 1:22c) —is in his desire to ensure that as many of the elements of the source text are represented in his rendering (e.g. Job 25:3-4; 26:13), without sacrificing its appeal to the reader by resorting to isomorphism and stereotyping.

It is this closeness to the Hebrew consonantal text of Sym.'s day that offers us the opportunity to identify elements that may be significant for textual criticism and the history of the textual development of the book concerned. In the case of Job, Sym.'s fragments may exhibit signs of a variant reading tradition (e.g. Job 24:25) and occasionally hint that he had a different consonantal text (e.g. Job 26:5; 29:4).

$61 \quad$ With thanks to Jan Joosten for this point.

62 Van der Louw, Transformations, 57 (italics original). 